2014-12-01

\title{
Palimtextual Tracts: Susan Howe's Rearticulation of Place
}

\author{
Bloomfield, Mandy
}

http://hdl.handle.net/10026.1/10277

10.1353/cli.2014.0039

Contemporary Literature

University of Wisconsin Press

All content in PEARL is protected by copyright law. Author manuscripts are made available in accordance with publisher policies. Please cite only the published version using the details provided on the item record or document. In the absence of an open licence (e.g. Creative Commons), permissions for further reuse of content should be sought from the publisher or author. 


\title{
Mandy Bloomfield
}

\section{Palimtextual Tracts: Susan Howe's Re-articulation of Place}

\begin{abstract}
This article examines American poet Susan Howe's engagement with landscape and place across the trajectory of her career, centrally examining three key poems: Secret History of the Dividing Line (1978), Thorow (1987) and Souls of the Labadie Tract (2007). In so doing, it demonstrates this work's pertinence for discussions of environmental aesthetics. Starting from the premise that Howe's poetic engagement with entangled historical and environmental questions is as much formal as it is thematic, I focus on two of her prominent techniques: the "palimtextual" excavation of source materials and the spatial use of the page. I argue that this poetry's entangled materialities play out shifting tensions and dialogues between a Romantic quest for a reconnection with "nature" and a constructionist awareness of the forms of mediation that shape the poetics of place.
\end{abstract}

In an account of the circumstances under which she wrote the poem Thorow during an extended stay at Lake George in 1987, Susan Howe writes:

If there is a Spirit of Place that Spirit had me in thrall. Day after day I watched the lake and how weather and light changed it. I think I was trying to paint a landscape... but my vision of the lake was not so much in space as in time. I was very aware of the commercialization and near ruin at the edge of the water, in the town itself, all around - but I felt outside of time or in an earlier time and that was what I had to get on paper. For some reason this beautiful body of water has attracted violence and greed ever since the Europeans first saw it. I thought I could feel it when it was pure, enchanted, nameless. There never was such a pure place. In all nature there is violence. Still it must have been wonderful at first sight. Uninterrupted nature usually 
is a dream enjoyed by the spoilers and looters - my ancestors. It's a first dream of wildness that most of us need in order to breathe; and yet to inhabit a wilderness is to destroy it. An eternal contradiction. (Howe, "Difficulties" 20-21)

Here we see the poet positioning herself ambivalently within a powerful tradition of "the poetry of place." From the narratives of the earliest European settlers, through the Romantic writings of Ralph Waldo Emerson, Henry David Thoreau and Walt Whitman to the modern poetry of William Carlos Williams, Hart Crane, Charles Olson and Gary Snyder, landscape and geography have played a central, albeit shifting, role in the American literary imagination. Howe explicitly invokes D. H. Lawrence's notion of a "Spirit of Place," which he understood as a "terrestrial magnetism," an elemental "vital effluence... vibration... chemical exhalation"(6) infused, as if by osmosis, into American writing. Finding this mystical sense of connection between writing and place compelling, she articulates a yearning to transfer onto paper something of the landscape's pre-colonial "wildness," its "vital effluence" untainted by the damage of subsequent history. But her initial "if" implies skepticism towards such notions. In particular, she highlights how historical violence has shaped this place and her relation to it, and also how, as the descendent of "spoilers and looters," she is implicated in this history. Furthermore, she recognizes that the very fantasy of "uninterrupted nature" in which she momentarily indulges is itself a construction that emerges from this history and culture of appropriation. Howe's prose thus oscillates between a seemingly naïve desire for an encounter with a primordial realm "outside of time," and a heightened awareness of the historical forces that have shaped the landscape and necessarily mediate all responses to it, including the very desire for unmediated encounter. This is indeed a poetics of place caught in "eternal contradiction."

Such conflicting impulses are typical of Howe's poetics more generally. As Brian Reed has so cogently observed, “[a] duck-rabbit combination of skepticism and transcendentalism 
is ... a foundational part of Howe's worldview"(para 28). I want to suggest that this characteristic feature of her work is particularly salient for environmentally-oriented debates about the poetics of place. The "eternal contradiction" performed by Howe's place-based imagination corresponds quite strikingly with an argument in ecocritical circles between strongly constructionist perspectives and what Greg Garrard neatly characterizes as "the poetics of authenticity," which seeks an "unmediated encounter with the real world that rescues the subject from the corrupt modern world of representation and simulation"(168).

This tension has been present within ecocriticism since its beginnings in the 1990s, when this emergent field defined itself against the poststructuralist "linguistic turn" in the humanities, seeking to reinstate nature as referent in the face of very real anthropogenic destruction. In Kate Soper's ubiquitously-cited formulation, “it is not language that has a hole in its ozone layer; and the 'real' thing continues to be polluted and degraded even as we refine our deconstructive insights at the level of the signifier"(151). Ecocriticism's "referential turn" led to a privileging of realist writing by some critics, such as Lawrence Buell, while others, such as Jonathan Bate, valued Romantic and post-Romantic poetry for its capacity "to speak 'earth"” (251) by invoking it experientially through rhythmic and sensuous dimensions of poetic language. Says Bate, "it could be that poesis in the sense of versemaking is language's most direct path of a return to the oikos, the place of dwelling, because meter itself - a quiet but persistent music, a recurring cycle, a heartbeat - is an answering to nature's own rhythms, an echoing of the song of the earth itself' (76).

However, some ecocritical approaches have been much less ready to abandon the lessons of poststructuralism, advancing arguments about the ways in which "nature" is alwaysalready constructed and mediated through cultural representations as entangled with hegemonic power relations. David Mazel, for example, in his book American Literary Environmentalism, "treats the environment as a discursive construction, something whose 
'reality' derives from the ways we write, speak and think about it'(xii), including the very discourses of environmentalism itself. For Mazel, American "nature" has historically been constructed through operations of power such as the subjugation, abjection and exclusion of native peoples from the scene of a "Virgin Wilderness," which then becomes the arena for manifest destiny and the building of America as "Nature's Nation" (xviii).

Such polarized positions are of course not wholly representative of the rich and heterogeneous array of perspectives which ecocriticism now comprises, but they do exemplify some crucial tensions which have not disappeared, even as the field has diversified and even as numerous ecocritical methodologies have complicated distinctions between objective materiality and discourse, nature and culture. Howe's oscillation between a keen awareness of the cultural constructedness of landscape - in many ways akin to Mazel's vision - and a desire for contact with a primordial wildness performs a thinking-through of the problematics of place, landscape and "nature" which is parallel to and contemporaneous with ecocriticism's debates. As Garrard asserts, a key challenge for this mode of criticism is "to keep one eye on the ways in which 'nature' is always in some ways culturally constructed, and the other on the fact that nature really exists, both the object and, albeit distantly, the origin of our discourse"(10). Howe's engagements with landscape can fruitfully be read as a poetic embodiment of the challenges of this undertaking.

While there are already many excellent essays, articles and book chapters on Howe's engagement with landscape, she has not yet been read as a particularly ecologically orientated poet. ${ }^{1}$ Critics have focused more on the sociohistorical than the environmental dimensions of her American landscapes. ${ }^{2}$ By emphasizing this poetry's engagement with ecological matters, I wish not only to extend the array of frameworks within which we can understand Howe's poetry, but also to suggest ways in which a close attention to these dimensions of her work can add to wider debates about the ethical stakes of environmental aesthetics. 
Ecocritical discussions of poetry have very strongly favored poets such as A. R. Ammons, Wendell Berry or Snyder. Such writers' explicit thematization of ecological relationships tends to focalize experiential encounters with "nature" through an ecocentrically-oriented lyric persona, via an insistently referential poetic language. More formally experimental work has largely been sidestepped, due to a lingering suspicion that attentiveness to the materiality of language amounts to an effacement of a world beyond textuality. ${ }^{3}$ One of my aims in this essay is to demonstrate that a poetics of foregrounded textuality does not equate to a withdrawal from the material world and an eschewal of environmental ethics. To the contrary, poetry by experimental writers like Howe has much to contribute to ongoing ecocritical deliberations about questions of language and the material world. For one thing, as we shall see, her work is of considerable interest for the ways in which it draws on and critically reworks the environmental aesthetics of a range of figures quite commonly discussed in ecocritical circles, such as Thoreau and Wallace Stevens. And while Howe has never declared a commitment to environmental issues as explicitly as those such as Jorie Graham, John Kinsella or Juliana Spahr, for example, her work can nevertheless be placed in productive relation to such broader poetic tendencies combining ecological thinking with various kinds of formal experimentation.

One of the outcomes of early ecocriticism's general aversion to textual artifice has been a tendency to focus more on literary works' thematic articulation of ecological issues than on questions of literary form. However, since Howe's work performs its “duck-rabbit" poetics of place through an emphatically material language, I shall pay a great deal of attention to the role of poetic forms in the work's negotiation of particular landscapes, and the larger aesthetic and ethical questions this encounter generates. One of the first things to note in this respect is Howe's abundant incorporation of source material gleaned from literary and historical archives and often incorporated without explicit acknowledgement into the poetic 
text. Her historical, environmental and philosophical investigations frequently proceed “through words of others"(Nonconformist's 92).

I draw on Michael Davidson's notion of the "palimtext" to characterize this dimension of Howe's landscape aesthetics. The "palimtext," Davidson explains, emphasizes the "multilayered quality of the material text" (Outskirts 6). The terms "multilayered" and "material" gesture towards both the formal and the social dimensions of textuality. Formally, the palimtext "retains vestiges of prior writings out of which it emerges. Or more accurately, the still-visible record of its responses to those writings"("Palimtexts" 78). But this aesthetic has a further materialist dimension: "[t]o dig down through the layers of the palimtext is to understand its multiple inscriptions in social materiality"(Outskirts 6). Such "social materiality," I want to suggest, is always imbricated with ecological materiality in ways that Howe's landscape poems make manifest. Composed of physically, conceptually and ideologically entangled layerings, these works are palimtextual tracts.

Tract, meanwhile, denotes both an area of land and a written text, thus invoking a chiasmus of text and land already implicit in the notion of a landscape. As W.J.T. Mitchell indicates, "[1]andscape is a natural scene mediated by culture. It is both a represented and a presented space, both a signifier and a signified, both a frame and what a frame contains, both a real place and its simulacrum"(5). Howe's work wants to keep this "both" (at least) in sight. Her poems simultaneously present themselves as landscapes, even as they investigate historical processes of the land's inscription and suggest its ontological unassimilability to textuality. Furthermore, her poems and poetic statements indicate multiple ways in which their own material forms are shaped by the specific actualities of place. As we shall see, the relationship between land and text is, unsurprisingly, never straightforward in this work.

The palimtext and the tract, then, indicate two intertwined formal dimensions of Howe's poetry upon which I particularly want to focus: the incorporation of source material into the 
poem and the scaping of the page itself as a physical site, a landscape or "word Forest"(Thorow 49). Both techniques have their roots in Howe's practice as a visual artist in the late 1960s and early 70s. Describing how a series of installation works she made during this time were pivotal in her move to writing poetry, she says "I had started making environments - rooms that you could walk into and be surrounded by walls, and on those walls would be collage, using found photographs ([...] a kind of quotation)"(“An Interview" 6). Here, she is already thinking of the work itself as an "environment," composed of found materials, and, increasingly, words. It was at about the same time that she also became aware of Olson's engagement with 'Space. North American Space - how it's connected to memory, war, and history"(5). So from her earliest beginnings as a poet, Howe was thinking about the spatial possibilities of the artwork, the material incorporation of source materials, and, in an Olsonian sense, the connections between the poem-as-field and geographic particularities.

These noteworthy dimensions of Howe's practice as she moved from visual art to poetry indicate an enduring interest in intertwined aesthetic, environmental and historical questions. In order to explore the trajectory of this persistent thread in Howe's poetics, I will examine three works spanning almost 30 years: the early series Secret History of the Dividing Line (1978), Thorow (1987) from Howe's middle period, and the late work Souls of the Labadie Tract (2007). Howe's engagement with specific American landscapes and their histories is especially prominent in these three key texts, but the shifting terms of this encounter also reveal changes in her negotiation of the relations between text and land. The early work presents a highly textualized understanding of landscape in its exploration and unsettling of the violent logics of colonial and capitalist inscriptions of the American continent. In Thorow this sensibility becomes tempered by both a sense of complicity with this history's cultural legacies and a heightened desire to acknowledge material actualities unsubsumable to constructivist understandings of landscape. Howe's later work shifts away from a 
preoccupation with the violence of colonial, capitalist and patriarchal histories, towards a poetic reactivation of the unfulfilled potentials of her literary-historical precursors. This process leads her to explore chiasmatic relations between language, "nature" and history. As I aim to show, textual materiality functions in these works both as a means for investigating the historical construction of the American landscape and as a site of encounter with its alterities.

\section{Boundaries}

Secret History of the Dividing Line is a poem which makes analogies between the space of the printed page and the landscape in order to explore power relations across these interrelated terrains. It can thus be read as an implicit rejoinder to Emerson's assertion that "America is a poem in our eyes; its ample geography dazzles our imagination, and it will not wait long for meters"(465). If Emerson imagines the land as a poem which overwhelms the senses and outstrips conceptualization, he also magisterially adopts the perspective of a surveyor who sees this voluptuous expanse as passively "waiting" for modes of measurement (both poetic and cartographic), to render it imaginatively mappable. While Howe undoubtedly shares some of Emerson's Romantic awe of the land's otherness, she is acutely conscious that any process of mapping does not merely chart a pre-existing reality but rather contributes to its imaginative and physical construction in ways that are entangled with the dynamics of power; "Measuring," as Thorow indicates, is contiguous with "mastering" (45).

An exploration of how Secret History of the Dividing Line engages with such issues can fruitfully begin with the poem's title, which references two different accounts of a 1728 surveying expedition authored by William Byrd: The History of the Dividing Line and The Secret History of the Line. Byrd was part of a team contracted to establish the disputed border between Virginia and North Carolina by marking a straight line through incredibly challenging terrain. Howe is drawn to his often playful accounts of this unenviable task because of their ambivalent articulation of a struggle for physical and imaginative control of 
the land. According to Roderick Nash, Byrd's narrative is "the first extensive American commentary on wilderness that reveals a feeling other than hostility”(51). Byrd moves between a "Romantic enthusiasm"(52) for the sublime "wilderness" and a pioneer attitude of antagonism towards an environment perceived as "doleful"(Byrd 284) and "desolate"(312). Elsewhere, Nash continues, he displays a frontiersman's idealization of the usefulness of natural resources (53). His narratives also portray the land not as an empty expanse, as in Emerson's geographic imagination, but as a landscape already marked by distinct ecologies, and by the presences of native Americans, European settlers and traders. Byrd's texts document processes of the American landscape's inscription and reinscription, literally and imaginatively, within multiple, often competing material practices and ideological frames.

From its first page, Howe's poem posits a parallel between textual and geographic space as a way of exploring the implications of running a dividing line through a landscape already marked by complex ecological, cultural and ideological processes:

mark mar ha forest 1 a boundary manic a land a
tract indicate position 2 record bunting interval
free also event starting the slightly position of
$\mathrm{O}$ about both or don't something INDICATION Americ

made or also symbol sachem maimed as on her for ar in teacher duct excellent figure MARK lead be knife knows his hogs dogs a boundary model nucle hearted land land land district boundary times un

(Frame Structures 89, copyright (C1974, 1975, 1978, 1979,1996 by Susan Howe. Reprinted by permission of New Directions Publishing Corp.)

As Rachel Tzvia Back has shown, the material here comes from the Webster's Dictionary definition for "mark." Like the word "tract," "mark" denotes both an inscription and land, 
originating in the Old High German marha, "boundary land." Furthermore, as a word grid arranged as two rigidly-defined blocks of text, the poem's layout visually references the surveyor's dividing line, and the grid formation that would follow Byrd's line to extend all over America. The page, then, presents itself as a landscape, a "tract" in both senses.

In so doing, this opening poem draws parallels between the power geometries of geography and those of printed language. Above all, its layout makes visible the ethical implications of the staking-out of tracts. Truncated words along the right-hand margins of the justified text, "Americ," "nucle," and "un," physically testify to the tyranny of "dividing lines" whose rigid trajectories do not neutrally plot, but violently sever. In particular, as Nick Selby has also noted, the absence of the feminine ending from "Americ" suggests an excision and silencing of the feminine in the construction of a nation through the subduing of so-called “virgin" land. Howe writes in My Emily Dickinson, "[e]xploration and settlement were pictured in terms of masculine erotic discovery and domination of alluring/ threatening feminine territory" (76). Echoing ecofeminist arguments, she emphasizes how patriarchal alignments of femininity and nature validate their mutual objectification and subjugation.

Furthermore, to imagine the land as "virgin" is to efface the presence of its prior inhabitants. As ecologists and geographers since about the 1950s have shown, the American continent encountered by the earliest European settlers and later westward-moving expansionists was not a pristine wilderness but a landscape materially shaped by native American practices of forest and prairie clearance, agriculture, hunting and travel. ${ }^{4}$ However, the image of a "virgin wilderness" as the scene of a fulfillment of manifest destiny has been a powerful and persistent component of America's foundational narratives. Howe's poem draws attention to the epistemic and material violence of this act of erasure via the sequence "sachem maimed," intimating brutality and damage to the native American people. In such 
critical moves as these we might detect an Adornian sense that the domination of nature goes together with the violent domination of social "others."

What becomes increasingly evident in the sequence that follows this initial poem is an entanglement between the violent logic of dividing lines and the transformation of land into property. Here we might note commonalities with a poet such as John Kinsella, whose interrogation of the concept of "property" stems from an acute awareness that the land he lives on in Western Australia is land historically stolen from the aboriginal Nyungar people through processes of “surveying, gifting, selling, claiming”(Gander \& Kinsella 78n). Howe's poem performs a parallel critique:

wire fences along property lines

I know the war-whoop in each dusty narrative (99)

These lines paratactically enact the relation between the dispossession and exclusion of the land's prior inhabitants (with whom the "war-whoop" is particularly associated) and the project of constituting notions of property which have been so central, and so fraught, in constructions of Americanness. ${ }^{5}$ In so doing, it traces this landscape's inscription not only within the logics of manifest destiny but also within a larger world historical system of expansionist capitalism. The demarcation and appropriation of property functions as a form of what Karl Marx refers to as “primitive accumulation,"(873) the acquisition of property through "conquest, enslavement, robbery, murder, in short, force"(874) which forms the "prehistory of capital"(875). Secret History makes palpable the multiple forms of this violence, from conflicts over land to the marginalization of women and racialized "others," some of whom, Howe's poem pithily suggests, were also considered "property" in a "whitewashed epoch"(115).

The effects of "primitive accumulation," however, are ecological as well as social. As Adrian Ivhakiv cogently points out, the capitalist world system is 
not only a political-economic one... but also a political-ecological one, in which the warp and woof of uneven development and global inequality are directly related to the ways in which advanced industrial capitalism both commodifies and thoroughly transforms the natural world and our relationship with it. (99)

Secret History highlights the effects of these processes:

the animals speak

impaled again

in a netting of fences (96)

Referencing the literal practice of enclosing property, and, furthermore, a conceptual dividing line separating the "human" from the other-than-human, the poem makes a link between the appropriation of land and the erection of an ontological fence which places "peculiar animals" "close to that nothing outside the circle"(115). According to Timothy Morton, the very category "animal" "is among the ways in which thinking reifies the ecological" ("Ecologocentrism" 76). The "animal," conceptually positioned "outside the circle" of the human, is placed at a distance and thus rendered as an object. As such, it can be accordingly expelled from the realm of human activity or instrumentalized by it, as are the horses to whom the phrase "peculiar animals" refers in Howe's probable source text here, James Fenimore Cooper's Last of the Mohicans. ${ }^{6}$ Indeed, the term "peculiar" points to an epistemological otherness of the animal, but it also leads back to notions of property, via an etymological trail; "peculiar" has its roots in the Middle English peculium "property," from pecu, "cattle” (cattle being "private property") ("Peculiar," Origin).

Thus the "dividing line" comes to have numerous wider ideological, gendered, racial, and ecological implications. However, as well as making visible the violent logic of the imagined geographies of the colonial project, Secret History's poetic landscapes also seek to unsettle 
them. Returning to the opening grid poem, it is apparent that its spatial arrangement not only references the violence of the dividing line, but also interrogates the conventions of the poetic line. This poem's layout disturbs the territory of the page in ways that suggest alternative terrains, or, as Selby puts it, "uncharted poetic territory”(57). Brian Reed has remarked that Howe's word squares "always appear at charged junctures, when the writing confronts the limits of cognition and representation"(para 53). The implication is that such a poetic practice intimates modes and knowing and perceiving not tied to the unitary directionality implied by the very notion of a poetic "line."

Firstly, the word grid's spatial rather than syntactical arrangement of words disrupts the usual process of reading and mapping meaning, making some terms hard to pin down, even at the most basic grammatical level. Are "mark," "position," "record" and the repeated "land" nouns or verbs? Do they denote things (primarily spatial, objectifiable, potentially commodifiable) or actions (temporal, and suggesting agency)? Such uncertainties counter the controlling aspirations of borders and boundaries. Furthermore, they obliquely put notions of "property" under pressure by frustrating the "possession" of meaning. But above all, the presence of so many terms and fragments associated with the word "mark" (the dictionary entry runs to an entire page) points to an unruliness of language which troubles the act of demarcating one space from another. The mark itself - the boundary - is shown to have a kind of thickness, both materially and conceptually. If the mark has a presence in and of itself, then the materiality of the mark, the space of the boundary, is a zone of indeterminacy, a "slightly position" that troubles absolute distinctions and categorizations. Howe's poem thus presents the boundary as a complex inscription, a palimtextual entanglement of competing forces.

By bringing together notions of the landscape as a text and the text as landscape, Secret History performs a critical enquiry into the ethical, representational and material stakes of 
boundary marking. The poem traces histories of the dividing line in its connection with notions of property so central to colonial and nation-building projects in America. Moreover, it strains towards alternative imaginings through its engagement with source materials and its spatial renegotiations of the poetic page which seek to render the (textual and material) landscape as a field of competing, coexisting and unresolved forces. Howe's poem encounters the landscape not as an empty terrain "wait[ing]... for meters" but as an alwaysalready written over site of inscription and reinscription. The palimtextual entanglements of Howe's tracts suggest that land and page might be re-articulated in ways that render such unfulfilled potentials palpable. Often it is the cognitively unmappable material dimensions of the page, the word and the mark, which most powerfully intimate such possibilities.

\section{Wildness}

Like Secret History, Thorow traces the patterns of violence decipherable upon the palimtextual landscape. But this poem displays a heightened impulse to achieve a sense of nearness to its suppressed, extinguished or unacknowledged dimensions. In Thorow's introductory prose section, Howe describes how, living for a time at Lake George in Upper New York State, she feels the area's deep past as a palpable presence: "I thought I stood on the shores of a history of the world where forms of wildness brought up by memory become desire and multiply"(40). As we shall see, Thorow reflectively explores the potentials of poetry to pursue "forms of wildness," and the aesthetic and ethical stakes of doing so. For one thing, it is not just this landscape's traces of "primal indeterminacy"(40) that the poet senses as a felt immediacy, but also "a history of the world" in whose violent colonial legacies the poet feels implicated. "My ancestors tore off / the first leaves"(52) proclaims one of the poem's voices, while another confesses, "Singing their War song / I am /Part of their encroachment"(47). 
Statements such as these signal the poem's own entanglement in the appropriations and "encroachments" of its historical and aesthetic predecessors, but its palimtextual use of source materials pursues this complex relationship further. Thorow derives a great deal of its textual resources from the papers of the eighteenth-century colonialist Sir William Johnson and the writings of Thoreau, both of whom have played important roles in shaping the American landscape, literally and imaginatively. ${ }^{7}$ Johnson, a prominent figure of the mid eighteenth-century French and Indian wars, led the British at the Battle of Lake George and built Fort William Henry there. Acting as a mediator between the native peoples and the British, he brokered treaties - such as the one at Fort Stanwix in 1784 - which gradually divested the Iroquois of their ancestral lands. His journals document a history of violent conflict over territory. Thoreau, meanwhile, as a surveyor, conservationist and literary figure, has been highly influential in shaping the American environmental imagination, not least through his "nature writing." Through the poetic incorporation of text directly lifted from these sources, Howe investigates the ways in which landscape is constructed and mediated. At the same, somewhat paradoxically, she seeks in this appropriated material the residues of “Unappropriated land"(50).

Thoreau's notion of the wild is particularly important for both of these dimensions of the poem. If Howe associates the primal with the indeterminate, as the prose introduction to her poem suggests, then it is in the language of prior textual negotiations with the landscape that she looks for traces of "wildness"(40). "Wildness" is not an externalized and objectifiable "wilderness," but something far more elusive. Jane Bennett helpfully describes Thoreau's notion of wildness as "the shadow of humanity's... relentless quest to domesticate life, a quest that Thoreau knows himself to be implicated in. Wildness is the remainder that always escapes taxonomies... or inventories... it is the difference of the woods that remains no matter how many times one walks them"(Thoreau's Nature 35-6). An unappropriable 
alterity, unsubsumable to epistemological imperatives, for Howe wildness is also the trace of an "outsideness" of the text, but held within the text, as "shadow," to use Bennett's apposite terminology.

This idea of wildness is explored throughout Thorow:

I have imagined a center

Wilder than this region

The figment of a book

Scarce broken letters

Cold leaden sky (54)

That the wild might be located in "The figment of a book" points both to textual constructions of the "wilderness" and the possibility of a form of "wildness" within the text that escapes precisely such formulations. "Wilderness" has a complex history in the American literary imagination. Early Puritan settlers' biblically framed and contradictory understandings of the American landscape as a hostile wilderness of exile, but also Edenic promise, constructed "wilderness" as a domain to be subdued. Romantic writing later revalued the "wilderness" in more celebratory terms as a site of encounter with the sublime. But as William Cronon has pointed out, the Romantic "cultural invention of wilderness"(16) has enacted a multiply problematic domestication of the wild as the source of an "authenticity" purged of human presence (hence the expulsion of native Americans from "wilderness" areas), and free from history (and therefore responsibility). Romantic writers such as Thoreau have, as both Bennett and Cronon indicate, participated in this construction.

Howe too, whose poetry must approach the wild through "words of others," finds her writing caught up in such prior inscriptions of "wilderness." And yet she is certainly not just 
a contemporary representative of this tradition. While she finds fantasies of " $[\mathrm{u}]$ ninterrupted nature" ("Difficulties" 21) highly compelling, she recognizes that any such notion is always already a cultural construction, and one largely complicit with colonialist, patriarchal and anthropocentric perspectives. And yet at the same time she remains committed to the notion of wildness. Despite slippages between the two terms, a distinction must be made between constructions of "wilderness" and the notion of "wildness" which Howe derives from Thoreau (a distinction which Cronon's otherwise careful analysis fudges). "Wilderness" can be understood as an objectified state of nature "out there" beyond the text, (problematically) imagined as separate from human activity. "Wildness," however, is a quality attributable equally to ontologically autonomous dimensions of material reality and to "othernesses" present within textual representation. Thus the lines from Thorow, quoted above, not only point to textual constructions of wilderness, they also suggest a fugitive "wildness," palpable, for instance, in "broken letters," or a fragmented language which does not function normatively. It is in the instabilities of textuality that the poem seeks an "understory of anotherword"(50), as if a trace of a primordial actuality is held within the text, on the underside of the word itself.

Nowhere is this sensibility more evident than in the final section of Thorow, which stages one of Howe's most dramatic instances of textual "wildness" (figure 1). Through the set of framing instructions placed at the center of these pages, Howe asserts a structural complicity between conventional page layout visually arranged to manage, order, and control textual material and the process of its decipherment, and the violent, constraining, instrumental logic of what Thorow refers to as the "European grid on the forest" (45). Says Rachel Blau DuPlessis, "The page is not neutral. Not blank, and not neutral. It is a territory" (131). In semantic terms, the territory of the page is undoubtedly unsettled here by the misspelling of "rabbet" (the rebated part in the back of a picture frame in which the artwork and sometimes 
the glass sits) as "Rabbit." With this slippage, the dictatorial instructions go awry, and are recast in relation to an Alice in Wonderland world of non-sense which destabilizes the "grid" of rationality that underpins them.

[Figure 1. Pages 56-7 from Thorow. 1987. Image from Singularities (C) 1990 by Susan Howe. Reprinted by permission of Wesleyan University Press.]

But of course it is the visual disruption of the page that is most immediately striking here. Rebelling against the usual rules of this territory, Howe's layouts scatter textual material derived from Johnson and Thoreau across the page to form dense, impenetrable thickets which semantically and materially enact wildness. Embodying the palimsestually entangled natural and cultural histories of the landscape, this arrangement induces literal textual tangles which generate unruly processes, as when "Hatchet" and "neck" almost collide, with somewhat obvious inferences. Semantically and in their visual arrangement, then, these poetic moves graphically approximate "wildness." However, I cannot quite concur with Back's reading of these pages as an enactment of "language's liberation, its release from the bonds of syntax, word units, and normative use of page space"(56) which represents a symbolic form of emancipation. Even in its most extreme disruptions of the page, Howe's poem retains an acute awareness of its own ensnarement within the language and ideologies of its own cultural legacy, and the embedded limitations of its own liberatory drive.

Furthermore, Howe's departure from "normative use of page space" does not in itself look quite so radical when placed in relation to visual artists' experimentation with words - she has frequently cited Carl Andre, John Cage and Robert Smithson's material language forms as particular influences here - not to mention the visual and concrete poetry of the $1960 \mathrm{~s}$ which she encountered through long-running conversations with the concrete poet, sculptor and landscape artist Ian Hamilton Finlay. However, what is rather unusual about Howe is that she brings visual experimentation together with historical and ecological questions. As I 
began to suggest in my introduction to this essay, we can trace this impulse back to her early career as a visual artist. ${ }^{8}$ In the early 1970s when her practice was shifting between visual art and poetry, Howe made a number of "list poems" consisting primarily of nouns pertaining to aspects of the natural world, which were often juxtaposed with images, often of birds or trees, or watercolor washes (see figure 2).

The list form of these early works is worth careful consideration. Howe's New York milieu of the early 70 s would no doubt have alerted her to the use of the catalogue form by poets such as John Ashbery and Frank O'Hara, although she was probably more directly conscious of how it featured in the work of second-generation New York poets like Bernadette Mayer and Maureen Owen. But the stripped-down, minimalist form of Howe's early list poems has most in common with Finlay's list poems of the late 1960s and 70s, some on paper and some carved in stone, which often list the names of boats or elements of landscape or seascape. Indeed, Finlay was influential for Howe at the time that she was moving from visual art to poetry, and she had a lengthy correspondence with him in the 1970s as well as writing about his work in a key critical article "The End of Art." Like many of the forms that Finlay self-consciously deploys in his own ambivalent negotiation of the aesthetic traditions of representing "nature," the list form references processes of cataloguing, categorizing, and managing which can be aligned with logics of domination and instrumentalization. But at the same time, non-hierarchical lists such as these have often been read - especially in Whitman's use of them - as an expansive formal gesture. Indeed, as Lawrence Buell points out, American Romantics such as Whitman and Thoreau valued the catalogue poem "as the closest verbal approximation they were able to achieve to the boundless vitality of nature"(“Catalogue Rhetoric” 187). In Howe's work, the list poem marks an encounter between (European) humanity and the land's "primal indeterminacy" (Thorow 40) which both recognizes how rationalizing systems of thought unavoidably 
structure this encounter but at the same time aspires, following the impulses of Romanticist precursors, to achieve an aesthetic approximation of such "boundlessness."

[Figure 2. Susan Howe, list poem with watercolor washes (original in color). The Susan Howe Papers, Mandeville Special Collections, UCSD. MSS 201, Box 15, Folder 8. Reprinted by permission of Susan Howe.]

The early verbal-visual list poem depicted as figure 2 is an interesting example of Howe's appropriation of this form for an investigation of entwined historical, ecological and aesthetic issues, and in particular the question of rendering wildness upon the poetic page. The work might at first appear to be an itemization of plants found, say, in a particular coastal locale, organized on the page in loose correlation with a spectrum of watercolor washes. These patches of color seem to correspond with some aspect of the named plant; sea holly, yellow flag and tansy, for example, sit opposite washes which echo their flower colors. However, it is certainly not the case that all the verbal and visual components line up in this way. Furthermore, almost none of the plants listed here are native to any particular American coastline, nor to any specific locale elsewhere; most are native to Europe or Eurasia, and are "cosmopolitan" in distribution. Many are present in North America as a result of colonial settlement and later global botanical trade; each has its own history. A number of these plants, such as white bryony, water milfoil and tansy, are now considered "invasive" species in some places. This is a cataloguing of "nature," then, as materially constituted through the material exchanges of imperial history and global trade. But even in its cataloguing aspirations the list poem's recorded "objects" slip away from rational epistemologies; there is no logic to this particular arrangement, except perhaps a lyrical logic, and some of the common names used here could refer to a number of different plants. The list can thus be read both as an aesthetic performance of a categorizing imperative, and as a gesture towards "wild" agencies which escape such domestication in both material and discursive senses. 
In Thorow, the catalogue poem reappears, this time specifically in connection with Howe's engagement with Thoreau; two lists of nouns gleaned from The Maine Woods and Walden make up part of the tangle of textual material in the pages depicted in figure 1. Through the use of this particular source material, arranged in catalogue form, Howe signals the extent to which Thoreau guides her poetic encounter with the land in Thorow. But she follows ambivalently in his footsteps. For all his respect for the natural world Thoreau unavoidably shared his culture's ideological lenses. As Buell points out (Environmental Imagination 213), his practices of land apportionment, for example, participate in the appropriations of the European settlers. And despite his admiration for indigenous peoples, Thoreau's writings often find themselves "under a spell of savagism” (Howe, Thorow 49), frequently portraying Native Americans in terms of a naïve simplicity that not only Romanticizes their ways of life, but infantilizes them and, as in the colonial imagination, tends to depict them as part of the landscape itself. Yet Howe is drawn to Thoreau precisely because of such tensions between the problematic and compelling aspects of his Romantic quest to imagine ways of approaching the "otherness" of the natural world and its inhabitants.

In Thorow, Howe's palimtextual lists of Thoreauvian nouns both use the list form that appeared so frequently in her earlier work and disrupt it. By printing her word series upsidedown or at odd angles and by tangling the orderly list up with other textual material, the written trace of an itemization of the natural world becomes a visual approximation of (textual) wildness. The literal materiality of the poem is central to this endeavor. For, as Peter Nicholls cogently puts it, Howe's writing “constantly courts the noncognitive in its preoccupation with graphic and phonic elements" ("Unsettling” 597). The quest for wildness here is not only - perhaps not even primarily - about linguistic play. Rather, this is “Apprehension as representation" (54) as a line of Thorow puts it. The poem offers 
apprehension as affect - as perception, as "noncognitive" sensation - as an analogue for an encounter with a "primal" dimension of the landscape.

Even in this privileging of the "noncognitive," Howe's writing finds itself entangled with the history of its landscape's representation, and in particular with the Romantic sublime. In lines such as "Walked on Mount Vision" (49), Thorow quite literally appears to follow in the footsteps of Thoreau's experience of the sublime atop Mount Katahdin, not to mention Cooper's staging of an encounter with the wilderness upon a mountain of that same name in The Pioneers, as Jenny White has pointed out (251-2). Furthermore, we might interpret Howe's pursuit of wildness in textuality as a transformed version of such encounters. As Ivhakiv puts it, "[t]he discourse of the sublime has been conspicuously resuscitated within postmodernist and poststructuralist writing as an indeterminate, ineffable alterity which hovers over against human attempts at comprehension"(106). Howe's pursuit of such an "ineffable alterity" at the level of textual materiality distinguishes her activities somewhat from the tendencies Ivhakiv identifies; in parallel with a Romantic transcendence of physicality, poststructuralist notions of indeterminacy tend to elide the question of the actual, physical materiality of the signifier in their privileging of semantic play. Nevertheless, Howe's encounter with landscape in Thorow works through the legacy of the sublime in its proffering of a "wild" material dimension of language which, although it insists on physicality, resists subsumption to discursive cognition.

For two of Howe's most astute commentators, Nicholls and Montgomery, this pursuit of wildness immanent in language entails a subsumption of material geography to textuality. Says Nicholls, “[t]he literal topography of 'borders' and 'margins' through which Howe maps early New England history is now elided with an equally literal topography of writing the actual page" (“Unsettling" 591 my emphasis). Montgomery, meanwhile, writes of Howe's "assimilation of the 'absolute freedom and wildness' that Thoreau found in Nature to 
the 'freedom and wildness' she found in libraries"(The Poetry 81 my emphasis). Indeed, Howe's apparent skepticism about the possibility of an immediate encounter with anything like "pure place," her investigation of literary and historical imaginings of the American landscape, and her own foregrounding of the material page as a landscape would seem to support this notion. However, her well-known conviction in history as "an actuality" (Birthmark 158) along with her appeal, no matter how ambivalent, to a "primordial" dimension of land in Thorow suggests that her poetry also understands material geography as "an actuality." I suggest, then, that Howe's textual "wildness" is offered not as a substitute for the material actuality of land, but as entangled and contiguous with it.

\section{Roots}

This question of the relationship between text and land is explored further in Howe's late work Souls of the Labadie Tract. One of the book's most powerful ideas is that of the library itself as a "sleeping wilderness" (14). This is not to say that textuality displaces nature as actuality, however. In an early prose section of Souls, entitled "Personal Narrative," Howe talks about walking through the landscape of Connecticut, whose "granite outcroppings, abandoned quarries, marshes, salt hay meadows, and paths through woods... put me in touch with my agrarian ancestors"(13). One is reminded here of numerous examples of writing, by those such as Ammons and Snyder, for example, in which walking enables a sense of closeness with a landscape's specificities. But Howe's prose moves swiftly to the library, where she describes herself "walking alone in the stacks, surrounded by raw material paper afterlife"(16). If we remember that "material paper" is quite literally an "afterlife" of the forested landscape, the link between these two scenarios becomes even more concrete. Howe positions her archival wanderings, and her sense of textuality's physicality, as contiguous to, rather than as a substitute for, an engagement with the material actuality of the land. 
The precise nature of this contiguity is somewhat differently inflected in Souls than in the earlier poetry. Like others of Howe's later works, Souls focuses less on the violence embedded in previous inscriptions of the landscape than in tracing a genealogy of the poet's voice as part of an aspiration to resuscitate the unfulfilled potentials of her literary-historical roots. Indeed, as we shall see, along with a host of other organic metaphors, the trope of roots is an important one for Howe's engagement with textuality and landscape in this work. From the outset, this series embraces a sense of migrancy, mobility and itinerancy often seen as an American cultural characteristic by emphasizing an interplay of writerly roots and routes, to lean on James Clifford's famous formulation. Several key figures, all of them writers and wanderers, feature prominently in the prose sections which provide narrative frames for the verse sequences. There is the eighteenth-century New England preacher Jonathan Edwards, who Howe pictures riding between his parishes, pinning scraps of paper to himself as reminders of insights which he would write down later. There is Hope Atherton, "lost in the great world of nature"(17), whose "wandering story" Howe claims as "the authority of a prior life for my own writing voice" (13). Another such figure is Jean de Labadie, seventeenth-century founder of a Dutch nonconformist Christian sect, whose “writing developed as a way of walking”(290) as Certeau puts it. After Labadie's death, his followers settled for a time in the tract of land in Maryland from which Howe's book takes its title, living according to an anti-institutional and egalitarian ethos. That the Labadists are “scattered and gone"(24) by 1727 makes them part of Howe's trans-historical tribe of wanderers on the margins of hegemonic American modernity. Another key figure is Wallace Stevens, who Howe describes as jotting down ideas during his walk to work, and these would later become poems. Finally, there is the renowned saunterer Thoreau.

These wandering predecessors' relations to place and landscape suggest a range of alternatives to hegemonic imperialist paradigms. Atherton's wanderings, for example, occur 
"before the land was subdued"(13), intimating the proximity of his narrative to unappropriated land. That the Labadists "held all property in common (including children)"(24), meanwhile, implies alternatives to capitalist individual property rights and a sense of "property" as stewardship, rather than ownership, since children, surely, cannot straightforwardly be considered "property." But for Howe these wanderers also represent a mode of writing shaped by the very process of moving through and engaging with particular landscapes.

Above all, Howe draws on the writing practices of Edwards and Stevens, two key figures around whom she structures her poem, to posit an intimate relationship between the literary imagination and the actuality of the organic world. In her essay "Choir answers to Choir," Howe asserts:

For Edwards, "the scheme of providence [is], like a tree above ground, gradually displayed as the branches successively put forth themselves." For Stevens, "All of our ideas come from the natural world: Trees = umbrellas." Time's disassociative force can't tear these two analogies apart. Spontaneous harmony retains the New England landscape from which they spring. (53-4)

In Edwards' and Stevens' "analogies," Howe finds something stronger than analogy, imagining the organic dimensions of the landscape as a shaping force from which these figures' writing and thinking “spring[s]." Here, again, is Lawrence's "spirit of place" but with a much more materialist emphasis than Lawrence gave it. Indeed, most especially in Souls, Howe yokes together the ghostly, the spiritual and the telepathic with the "felt fact"(9), often posited as an intuitive immediacy of the material text. If, as Howe proposes, the landscape itself shapes the very forms of American writing and thought, then spectral traces of that landscape - as it has been multiply imagined and materially constructed at different points in history - are palpable in writing. 
Furthermore, the "ghosts" of these material actualities, held in seemingly unlikely or arbitrarily chosen textual details, Howe asserts, "can be reanimated by appropriation" (Souls 15). The prose section of Souls entitled "Personal Narrative" performs such a "reanimation" by recycling textual materials derived from various sources: Hope Atherton's narrative as related in George Shelton's A History of Deerfield Massachusetts, her own poem Articulation of Sound Forms in Time which draws on that material, and, most importantly for my purposes, Thoreau's essay "Walking."

The palimtextual practice so emphatically and self-reflectively performed in the "Personal Narrative" section of Souls corresponds to a "composting sensibility"(1) which Jed Rasula celebrates as characteristic of American modernism. The compost metaphor is useful for what it suggests about the transformative processes of appropriation; just as the decompositions of compost create the fecund basis for new growth, so the textual compost might enable an equivalent "reanimation" of apparently dead matter. Howe's prose emphasizes this parallel via a composting of Thoreau's own compost aesthetic. Echoing his declaration that "Decayed literature makes the richest of all soils"(Journal 362), Howe writes “Often a damaged edition's semi-decay is the soil in which I thrive"(15). Thoreau speaks of the poet

who could impress the winds and streams into his service, to speak for him; who nailed words to their primitive senses, as farmers drive down stakes in the spring which the frost has heaved; who derived words as often as he used them transplanted them to his page with earth adhering to their roots; whose words were so true, and fresh and natural that they would appear to expand like the buds at the approach of spring. ("Walking” 650)

Howe proclaims, 
I wanted to transplant words onto paper with soil sticking to their roots - to go to meet a narrative's fate by immediate access to its concrete totality of singular interjections, crucified spellings, abbreviations, irrational apprehensions, collective identities, palavers, kicks, cordials, comforts. I wanted jerky and tedious details to oratorically bloom and bear fruit as if they had been set at liberty or ransomed by angels. (Souls 16)

Both describing and enacting a compost poetics, Howe reworks the mulch of Thoreau's organic metaphors to verbally perform an expansion of their generative potentials. Loosed from his rather constraining vocabulary of impressing, nailing and staking, Thoreau's images are provisionally "set at liberty" in a new context, where transplanted words might not only "expand like... buds" but "oratorically bloom and bear fruit." Howe transforms Thoreau's catalogue-like form, where clauses progress in a tightly controlled manner, into a list that piles up a heterogeneous array of rather bizarre textual "items." These constitute not so much a "totality" as a collection that seems quite untotalizable. The palimtextual compost here becomes a "concrete" performance of wildness, exploiting the fertility of Thoreau's own words. Although Thoreau aspires to harness something of a perceived immediacy of the natural world in writing, for him such immediacy is only available in the encounter with a reality beyond the text. But for Howe, an experience of immediacy is possible in the encounter with the text, and most especially the material text. Where Thoreau wished "to speak a word for Nature," Howe wishes "to speak a word for libraries as places of freedom and wildness"(16).

In Rasula's rendering of American compost poetics (both as described and enacted in his own writing), ecology is predominantly a metaphor for intertextuality. Although Howe wishes "to speak a word for libraries" rather than a Thoreauvian "Nature," her parallels between the wild and libraries do more than draw on the imaginative fecundity of organic 
figures; the connection between textuality and organic land goes further than the merely analogical. As she puts it in a discussion with Al Filreis, "the landscape enters through words. I mean literally words have the power to represent what was once, what is gone now in the landscape but was there somehow...”(Discussion at Kelly Writers' House). Howe's emphasis on literalness asserts a nearness of the material text to an experience of physical actuality; what she calls "the felt fact"(Souls 9) is an affective charge of language forms which evoke a landscape - and its suppressed or excised dimensions - as tangible presence.

In the title poem of Souls, which focuses most tightly on the land of the "Labadie Tract," landscape is not only evoked by lines such as "valley nothing but green"(29), and references to ecological relations like "silk moth fly mulberry tree"(29), but also in the material spaces created by the poem. Each of Howe's spare 5-8-line poems sits isolated in the center of the page in a manner that draws attention to the page as space. Such an evocation of spatiality takes on further dimensions in Howe's collaboration with David Grubbs in the sound performance of Souls ${ }^{9}$. One of a series of such collaborations (including a CD recording of parts of Thorow, renamed Thiefth), the sound version of Souls combines Howe's readings of the poem with Grubbs's haunting drones to create a piece that is highly evocative of a process of moving through spaces populated by palpable but indefinable presences. Both in their book-based and performed versions, poems like the following connect a materiality of poem space with a sense of geographic space. Here, my manner of quoting imitates the layout of two facing pages in order to indicate these spatial dimensions:

To swim for sake of rhyme

for meter faint letter slield

in pencil after subscribeth
White line of a

hand's breadth

A white wall a

door any place 
Shorthand on it because of

streights all glue for strife

Millenial hopes

certainly part of it

(Souls of the Labadie Tract 42-3, copyright (C2007 by Susan Howe. Reprinted by permission of New Directions Publishing Corp.)

In the verso page poem, "crucified spellings" and "jerky and tedious details" derived from archival wanderings create a semantic field that is ambiguous, strange, slippery. The poems' archaic spellings, unsettling paratactic leaps, and meanderings of logic dance along the borders of legibility and intelligibility, evading the directness of "streights" and the "glue" of comprehension. In so doing, these language forms intimate an "other" sense - the jostling presence, for instance of "slide," "shield" and "lied," just to mention a few of the possibilities, in "slield."

But this palpable otherness inheres most especially in the non-linguistic affective charge of the work. Both on the page and in the sound piece, Souls invokes the materiality of its own space - the space of the page or the soundscape - to create spaces and scapes to imaginatively dwell in and move through. The large amounts of white page space hint at the possibility of "wild" space not entirely appropriated by the "streights" of human activity, but co-existent with it. In the sound recording of Souls, meanwhile, Grubbs's drone sounds, made with a reed instrument (called a khaen), carry the timbre of the organic landscape. By bringing to attention such spatial, non-linguistic dimensions, the poem takes the processes of signification further into the wilds of meaningfulness and cognition. That these affective dimensions resist linguistic or conceptual enclosure or possession suggests possibilities for imaginatively inhabiting the land "otherwise."

Such possibilities, Howe wants to suggest, are held as submerged potentials in the soil of "semi-decay[ed]" texts. The title poem of Souls closes with one such archival item, a 
facsimile of a map fragment taken from Dennis Griffith's 1795 map of Maryland covering the area in which the Labadists had lived. The use of such facsimiles is a notable feature of Howe's later works, from Pierce-Arrow onwards, in which the material reproduction of various archival fragments carries an amplified affective charge. In Souls, this charge is intensified by Howe's pointed description of the "Lappadee Poplar" as "the one tree singled out on the entire map of the state"(24). As one of the few surviving remnants of the "souls of the Labadie tract," the marked tree is a trace of the tangled histories of the landscape's inhabitation, and the unfulfilled potentials held therein. Long concealed by hegemonic imperatives, such presences are nevertheless still tangible in a landscape which the poem reveals as a zone of entangled and competing histories.

For all that we are aware, as is Howe, that maps are acts of power, this map is presented as offering yet another way of imaginatively inhabiting the landscape. The palimtextual materiality of this document, the archaic quality of its drawing and writing, physically evinces intertwined processes of the land's historical inscription and reinscription and implies therefore the tangibility of this landscape's latencies. Furthermore, the tree-like branching of its rivers recall the motifs of roots, routes, rivers and branches that run through Souls, and which are not only suggestive of "trains of associative thought"(The Poetry 160) as Montgomery points out, but of other kinds of more material connectivity: an interaction between texts, between landscapes past and present, between texts and material geographies, and between human and non-human dimensions of the landscape.

\footnotetext{
Although not often remarked upon either by the poet or her commentators, Howe's engagement with the ecological dimensions of American landscape and history is a thread woven through the trajectory of her career. This is not to claim that her approaches to landscape or nature have remained constant or even consistent. Indeed, as I have suggested
} 
from the outset, Howe's poetics of place has shifted over her career and is characteristically conflicted and contradictory in each of its moments. Her work emphasizes the extent to which geographies are culturally constructed and mediated, and yet also insists on a material actuality of the land not entirely assimilable to these constructions. Howe's poetry embodies what she has recently characterized in an interview as a "magpie ambivalence... a Romantic, utopian ideal of poetry as revelation at the same instant it's a fall into fracture and trespass”(“Susan Howe: The Art of Poetry No. 97”). For her, such frictional impulses are a particularly American characteristic, a cultural legacy traceable from her Puritan and Romantic forebears to modernist precursors such as Crane, Pound, Stevens and Williams, Stevens, Crane and Pound. Indeed, I have focused in this essay on Howe's North American landscapes because it seems to me that it is here that these tensions are most apparent. While I would not want to make too sharp a distinction between the poet's "American" and "Irish" works, an examination of the Irish works might nevertheless yield rather different perspectives on issues of language, landscape and history. Howe's Irish landscapes are inflected by a different colonial history, which is not quite so sharply felt as in the American poems, and a distinct literary legacy in which pastoral or "sylvan / imagery"(Europe 89) is more prominent than conceptions of "wilderness" specific to the American context.

Part of Howe's fraught ambivalence in her engagements with landscape stems from a heightened sense of her own cultural implication in a history of damage to the land and its inhabitants - human and non-human - and her poetry's own incapacity to entirely move beyond this legacy as it is embedded in aesthetic engagements with place, landscape and nature. And yet her work pursues a wildness that suggests precisely the possibility of transcending such limitations. As we have seen, such tensions between broadly constructionist and broadly Romantic approaches to landscape are embodied in formal techniques which function both as a means of investigating the historical processes of the 
landscape's construction, and as a route to an encounter with alterities. Through the use of the space of the poetic page or the soundscape of the performed poem as environment, this poetry makes links between poetic space and the spatiality of the land. The pursuit of wildness through both semantic instabilities and material dimensions of the poem resistant to linguistic appropriation functions as an analogue for modes of encountering wildness beyond the space of the poem.

But Howe's work goes further than this, to posit something stronger than analogy between text and landscape. Most especially through her use of textual material appropriated from a variety of source texts, her work also claims a material connection between textuality and land, both in the sense that texts shape landscapes imaginatively and physically, and in the sense that texts are shaped by the landscapes from which they "spring." While her use of source texts involves an apparent eschewal of the Romantic ideal of immediacy achieved through the solitary individual's encounter with nature, Howe's poetry never entirely moves away from Romantic paradigms. Indeed, at times we might read her work's foregrounding of the affective dimensions of language as a transformed, materialist version of Romanticist engagements with landscape. Such leanings become ever stronger in the later work, where her conviction that the unfulfilled potentials of her source texts' connections to the land "can be reanimated by appropriation" takes on an almost mystical intonation. And yet if residual notions of a "Spirit of Place" animate the work, this "Spirit" is always rendered in highly material terms.

Perhaps, then, the material sensibility of Howe's poetics of place might be fruitfully brought into conversation with recent developments in ecocritical theory, namely with respect to the "new" materialisms and object-oriented ontologies expounded by those such as Stacy Alaimo, Karen Barad, Jane Bennett, Ian Bogost, Timothy Morton and Serpil Oppermann. As I have already mentioned Bennett and Morton in my earlier discussions, they are worth 
returning to in my closing remarks. Both draw on Romantic writing to theorize the ontologies and agencies of non-human entities. Bennett, for example, asserts a parallel between what she calls "thing-power" (or non-human agency) and Thoreau's notion of the wild, understood as "a not-quite human force that addled and altered human and other bodies"(Vibrant 2). Thoreau's practice of minute observation of particulars is also a guiding force in her encounter with the agency of material things. Morton, meanwhile, often uses examples from British Romanticism; in an essay entitled "An Object Oriented Defense," for example, he reads Shelley's figure of the Aeolian harp as embodying a mode of thinking that centers attention on the autonomous ontology of objects. An instrument that does not require a human player, the Aeolian harp exemplifies Morton's attempt to approach objects and their strangeness beyond their correlation with a human "subject."10

But what if we bring these thinkers' "materialist" reinterpretations of Romanticism into relation with Howe's parallel move? It rapidly becomes apparent that in contrast to Howe's textual opacities, Bennett and Morton quickly transcend textuality in their attempts to think about objects or things. For Bennett's Thoreau, the wild (and the associated "thing-power") is "the uncanny presence that met him in the Concord woods"(2), in the world-in-itself beyond language. Morton, meanwhile, is only too happy to state that texts are objects, and in a 2012 essay goes so far as to eulogize the poetic object as "an entity in its own right" ("An Object Oriented Defense" 222) which "force[s] the reader to coexist with fragile phrases, fragile ink, fragile paper: to experience the many physical levels of the poem's architecture"'(222). And yet he is much more interested in the material quality of the poem's depicted object (such as the Aeolian harp, the particular wood if its construction, the vibration of its strings, and so on) than in the "architecture" of the poem itself. Furthermore, because for Morton objects' ontologies are discrete, he eschews the question of relations between such textual physicality 
and other kinds of material entity. Such versions of "materialism" (or "realism" as Morton increasingly insists) are highly invested in a notion of the material world-in-itself.

Howe's materialism, though, retains from the "old" social and historical materialisms a wariness about such notions. Even as her poetry affectively gestures towards physical actualities, transcendent impulses are always tempered by "a fall into fracture and trespass." And yet her poetry registers the material world as a force that tangibly marks the poetic text; "wildness" might be encountered not just in the woods but also in the "word Forest." Such explorations of complex interdependencies between textual and material terrains seem crucial to keep in view as ecocritical materialisms attempt to "make it new."

\section{Works Cited}

Back, Rachel Tzvia. Led by Language: The Poetry and Poetics of Susan Howe. Tuscaloosa: U of Alabama P, 2002.

Bate, Jonathan. The Song of the Earth. London: Picador, 2000.

Bennett, Jane. Thoreau's Nature: Ethics, Politics, and the Wild. [1994]. Lanham, MD:

Rowman \& Littlefield, 2002.

_. Vibrant Matter: A Political Ecology of Things. Durham \& London: Duke U P, 2010. Buell, Lawrence. "Catalogue Rhetoric.” Literary Transcendentalism: Style and Vision in the American Renaissance. By Buell. Ithaca \& London: Cornell UP, 1973. 166-187.

- The Environmental Imagination: Thoreau, Nature Writing, and the Formation of American Culture. Cambridge, MA: The Belknap Press of Harvard UP, 1995.

Byrd, William. The Prose Works of William Byrd. Ed. Louis B. Wright. Cambridge, MA: The Belknap Press of Harvard UP, 1966.

Certeau, Michel de. The Mystic Fable: The Sixteenth and Seventeenth Centuries. Trans. Michael B. Smith. Chicago: U of Chicago P, 1992. 
Clifford, James. Routes: Travel and Translation in the Late Twentieth Century. Cambridge, MA: Harvard UP, 1995.

Cooper, James Fenimore. Last of the Mohicans. [1826]. London: Collector's Library, 2004.

Cronon, William. "The Trouble with Wilderness: Or, Getting Back to the Wrong Nature." Environmental History 1. 1 (1996): 7-28.

Davidson, Michael. On the Outskirts of Form. Middletown, CT. Wesleyan UP, 2011.

_. "Palimtexts: Postmodern Poetry and the Material Text." Postmodern Genres. Ed. Marjorie Perloff. Norman \& London: U of Oklahoma P, 1988. 75-95.

Denevan, William M. “The Pristine Myth: The Landscape of the Americas in 1492.” Annals of the Association of American Geographers 82.3 (1992): 369-85.

DuPlessis, Rachel Blau. The Pink Guitar: writing as feminist practice. New York \& London: Routledge, 1990.

Emerson, Ralph Waldo. “The Poet.” [1844]. Ralph Waldo Emerson: Essays and Lectures. New York: The Library of America, 1983. 447-70.

Finlay, Ian Hamilton. Wave Rock. Sculpture in glass. 1966.

Gander, Forrest and John Kinsella. Redstart: An Ecological Poetics. Iowa City: U of Iowa P, 2012.

Garrard, Greg. Ecocriticism. London \& New York: Routledge, 2004.

Hersey, Eleanor. “'Space Is a Frame We Map Ourselves In’: The feminist geographies of Susan Howe's Frame Structures." The Greening of Literary Scholarship: Literature, Theory and the Environment. Ed. Steven Rosendale. U of Iowa P, 2002. 131-148. Holmes, Oliver Wendell. Touched With Fire: Civil War Letters and Diary of Oliver Wendell Holmes. Ed. Mark De Wolfe Howe. [1946]. New York: Fordham UP, 2000.

Howe, Susan. The Birth-mark: Unsettling the Wilderness in American Literary History. Middletown, CT: Wesleyan UP, 1993. 
. "Choir Answers to Choir: Notes on Jonathan Edwards and Wallace Stevens."

Chicago Review 54. 4 (2009): 51-61.

—. "The Difficulties Interview." Conducted by Tom Beckett. The Difficulties 3.2 (1987): 17-27.

—. "Discussion During the Kelly Writers House Fellows Program, March $23^{\text {rd }} 2010 . "$ Conducted by Al Filreis. Pennsound Center for Programs in Contemporary Writing.

Web. 22 Aug. 2012. <http://writing.upenn.edu/pennsound/x/Howe.php>

_. "The End of Art." Archives of American Art 14.4 (1974): 2-7.

—. The Europe of Trusts. New York: New Directions, 1990.

_ . "An Interview with Susan Howe.” Conducted by Lynn Keller. Contemporary Literature 36.1 (1995): 1-34.

_. My Emily Dickinson. Berkeley: North Atlantic Books, 1985.

—. The Nonconformist's Memorial. New York: New Directions, 1993.

_. Pierce-Arrow. New York: New Directions, 1997.

Howe, Susan and David Grubbs. Souls of the Labadie Tract. Blue Chopsticks. 2007. CD.

—_. "Preface: Frame Structures.” Frame Structures: Early Poems 1974-1979. New York: New Directions, 1996. 1-30.

- Secret History of the Dividing Line. [1978]. Frame Structures: Early Poems 19741979. New York: New Directions, 1996. 87-122.

—. "Speaking with Susan Howe.” Conducted by Janet Ruth Falon. The Difficulties 3.2 (1987): $28-42$.

- Souls of the Labadie Tract. New York: New Directions, 2007.

—. "Susan Howe.” Pennsound Center for Programs in Contemporary Writing. Web. 10 Oct. 2012. 
—. Susan Howe Papers, MSS. 201. Mandeville Special Collections. U of California, San Diego. Accessed 27 May-1 Jun. 2007.

—. "Susan Howe, The Art of Poetry No. 97." Interview conducted by Maureen N.

McLane. The Paris Review 203. Winter 2012. Web. 2. Oct. 2013.

—. Thiefth. Blue Chopsticks. 2005. CD.

_. Thorow. [1987] Singularities. Middletown, CT: Wesleyan UP, 1990. 39-59.

Ivhakiv, Adrian. "Stirring the Geopolitical Unconscious: Towards a Jamesonian

Ecocriticism.” New Formations 64 (Spring 2008): 98-109.

Joyce, Lisa. “"Thorowly’ American: Orienteering in the Adirondacks.” Electronic Book Review, 1 Sept. 1996. Web. 1. Jul. 2012.

Keller, Lynn. “Beyond Imagining, Imagining Beyond.” PMLA 127.3 (May 2012.): 579-585.

Kingsland, Sharon E. The Evolution of American Ecology 1890-2000. Baltimore: Johns Hopkins UP, 2005

Lawrence, D.H. Studies in Classic American Literature. London: William Heinemann 1924.

Marx, Karl. Capital: A Critique of Political Economy. [1897]. Trans. by Ben Fowkes. Vol. 1. London: Penguin, 1990.

Mazel, David. American Literary Environmentalism. Athens: U of Georgia P, 2000.

Mitchell, W.J.T. “Imperial Landscape.” Landscape and Power. Ed. Mitchell. $2^{\text {nd }}$ Ed. Chicago: U of Chicago P, 2002. 5-34.

Montgomery, Will. “Appropriating primal indeterminacy: language, landscape and postmodern poetics in Susan Howe's Thorow." Textual Practice 20.4 (2006). 739757.

- The Poetry of Susan Howe: History, Theology, Authority. New York: Palgrave Macmillan, 2010.

Morton, Timothy. "Ecologocentrism: Unworking Animals.” SubStance 37.3 (2008): 73-96. 
—_. “An Object-Oriented Defense of Poetry.” New Literary History 43.2 (2012): 205224.

Nash, Roderick. Wilderness and the American Mind. 4th Ed. New Haven CT New Haven CT: Yale UP, 2002.

Nicholls, Peter. "The Pastness of Landscape: Susan Howe's 'Pierce-Arrow'.” Contemporary Literature 43.3 (2002): 441-460.

_ . "Unsettling the Wilderness: Susan Howe and American History." Contemporary Literature 37.4 (1996): 586-601.

“Peculiar.” Origin. Concise Oxford English Dictionary. 2002.

Rasula, Jed. This Compost: Ecological imperatives in American poetry. Athens GA: U of Georgia P, 2002.

Reed, Brian. “"Eden or Ebb of the Sea': Susan Howe's Word Squares and Postlinear Poetics.” Postmodern Culture 14.2 (2004). Web. 11 Jan. 2007.

Russo, Linda. "Writing Within: Notes on Ecopoetics as Spatial Practice." How2 3.2 (Summer 2008). Web. 14. Jan 2012.

Selby, Nick. "“Created Space": Mapping America as Poem in Gary Snyder's 'Mountains and Rivers without End' and Susan Howe's 'Secret History of the Dividing Line'.” Journal of American Studies 39. 1 (2005): 41-64.

Skinner, Jonathan. "Boundary Work in Mei-mei Berssenbrugge's 'Pollen'.” How2 3.2 (Summer 2008). Web. 14. Jan 2012.

Soper, Kate. What is Nature? Oxford: Blackwell, 1995.

Tarlo, Harriet. “Radical Landscapes.” Jacket 32 (April 2007). Web. 1 May. 2012.

Thoreau, Henry D. The Journal of Henry D. Thoreau. Ed. Bradford Torrey and Francis H. Allen. Vols I - VII (1837-1855). New York: Dover Publications, 1962)

—. The Maine Woods. [1864]. Princeton: Princeton UP, 2004. 
"Walking." [1862]. Walden: Or Life in the Woods and Other Writings. Westminster, MD: Modern Library, 2000. 625-663.

White, Jenny L. "The Landscapes of Susan Howe's 'Thorow'.” Contemporary Literature 47.2 (2006): 236-260.

\section{Acknowledgements}

I wish to thank Susan Howe for her permission to reproduce materials from the UCSD archive, and also Michael Davidson and Lynda Claassen for facilitating my research there. Thanks to Tom Beckett, editor of The Difficulties, for his permission to quote at length from the interview he conducted with Howe. I am also grateful to to New Directions for permission to reprint material from Frame Structures and Souls of the Labadie Tract, and Wesleyan University Press for permission to reproduce material from Singularities.

\footnotetext{
${ }^{1}$ See essays by Lisa Joyce, Will Montgomery, Peter Nicholls, Nick Selby and Jenny White as fine examples of such criticism.

${ }^{2}$ Selby's and White's superb essays are, to an extent, notable exceptions. Selby's constructionist stance positions Howe's Secret History as a more savvy "mapping” of American ideological constructions of the land than Snyder's Romanticist elegiac work. White's primary interest is the influence of James Fenimore Cooper on Howe's Thorow, and in histories in which violence is imagined in human terms, rather than in a wider ecological sense. An essay by Eleanor Hersey, published in a book called The Greening of Literary Scholarship focuses on feminist geography in Howe's prose writing and does not pursue more inclusive ecocritical concerns nearly as far as I want to here.

${ }^{3}$ This state of affairs is rapidly changing, however, with critics and poet-critics such as Lynn Keller, Linda Russo, Nick Selby, Jonathan Skinner and Harriet Tarlo arguing for the value of experimental poetics for ecocriticsm.
} 
${ }^{4}$ See Sharon Kingsland's account of Carl Sauer's studies of early human impacts on ecologies of the American continent (165-7) and William Denevan's discussion of how ecologists challenged the myth of a "pristine" wilderness from mid-century onwards. ${ }^{5}$ It is worth noting that Secret History draws material from Oliver Wendell Holmes's published letters and memoirs of the Civil War, edited by Howe's father. Issues of property, and particularly the question of humans as property, were of course central to The Civil War. ${ }^{6}$ Jenny White fruitfully explores Cooper's influence in Thorow. Howe also draws on this source in Secret History.

${ }^{7}$ Montgomery's meticulously researched article "Appropriating primal indeterminacy" and its revised form as chapter of The Poetry of Susan Howe give an excellent account of Howe's engagement with these sources.

${ }^{8}$ The Susan Howe Papers in the University of California San Diego's Mandeville Collection contain materials related to her installation entitled "Walls" of 1969-71, which I mentioned earlier as a formative work in the development of her landscape poetics. "Walls" comprised a number of vertical boards, upon which were juxtaposed photographs of birds, trees, and forest scenery, images of stone walls (the imported legacies of the eighteenth-century English enclosures), historical documentation referencing bird calls and snow, and in one "Wall" a found text expressing a concern that "with the coming of cats, pigs, and rats, the birds will disappear”(MSS. 201, Box 15, Folders $1 \&$ 5).

${ }^{9}$ The is available on $\mathrm{CD}$, but a performance of the piece, and others, can also be found at the author's page at Pennsound.

${ }^{10}$ It is perhaps necessary to acknowledge that humans are also "objects" in this ontological framework. 